\title{
Pengembangan Formula Nanoemulsi Air dalam Minyak Biji Anggur (Vitis vinifera L.) sebagai Basis Lipstik
}

\author{
Siti Z. Munawiroh ${ }^{1,2}$, Agenilia Permatasari ${ }^{1}$, dan Lutfi Chabib ${ }^{1,2}$ \\ 1 Jurusan Farmasi, FMIPA, Universitas Islam Indonesia, Yogyakarta, Indonesia \\ ${ }^{2}$ Nanofabrication Research Center, Laboratorium Teknologi Farmasi, Jurusan Farmasi, Universitas Islam Indonesia, \\ Yogyakarta, Indonesia
}

Korespondensi: Siti Z. Munawiroh

Email: sitizahliyatul@uii.ac.id

Submitted: 08-03-2019, Revised: 25-03-2019, Accepted: 26-11-2019

\begin{abstract}
ABSTRAK: Penelitian ini bertujuan untuk mengembangkan sediaan lipstik dengan basis nanoemulsi air dalam minyak biji anggur yang dibuat dengan energi rendah. Nanoemulsi air dalam minyak biji anggur energi rendah disiapkan dengan teknik phase inversion composition (PIC) pada suhu $80^{\circ} \mathrm{C}$ dengan menggunakan campuran surfaktan (tween 20/span80). Pada diagram terner (minyak biji anggur:air:campuran surfaktan), area terbesar terjadi pada rasio tween 20 dan span 80 (1:1). Rasio dapat dibuat nanoemulsi air dalam minyak biji anggur dengan kadar air maksimum mencapai 20\% dan jumlah surfaktan 60\%. Nanoemulsi air dalam minyak biji anggur dengan kadar air 6, 10, dan $14 \%$ dapat menghasilkan ukuran partikel yang terdistribusi secara tunggal (unimodal) dengan ukuran partikel secara berurutan 29,33 \pm 5,30; 30,23 \pm 7,33; dan 29,83 $\pm 11,47 \mathrm{~nm}$. Kandungan air pada nanoemulsi air dalam minyak biji anggur tidak berpengaruh pada karakteristik fisik lipstik (titik lebur dan kekerasan) sehingga dapat disimpulkan bahwa nanoemulsi air dalam minyak biji anggur yang disiapkan dengan teknik PIC dapat dikembangkan untuk basis lipstik.
\end{abstract}

Kata kunci: basis lipstik; energi rendah; minyak biji anggur; nanoemulsi air dalam minyak

\begin{abstract}
The objective of this research is to develop water in grape seed oil nanoemulsions which prepared by low energy method to be used in lipstick base formulation. Water in grape seed oil nanoemulsions were prepared by low energy methods which was employed a Phase Inversion Composition (PIC) technique in elevated temperature at $80^{\circ} \mathrm{C}$ using mixed-surfactants (tween $20 / \mathrm{span} 80$ ). In ternary phase diagram (oil:water:mixed-surfactants), the largest area of nanoemulsions was occurred in equal ratio tween 20:span 80 (1:1). The maximum water content of water in grape seed oil nanoemulsions was reached at 20\% water with 60\% mixed-surfactants (1:1). An unimodal size distribution of water in grape seed oil nanoemulsions with varied water content at 6, 10, and 14\% were found with droplet size at $29.33 \pm 5.30,30.23 \pm 7.33$, and $29.83 \pm 11.47 \mathrm{~nm}$. Water content of water in grape seed oil nanoemulsions insignificantly affected to melting profile and hardness properties of lipstick. Water in grape seed oil nanoemulsions which was prepared by low energy can be developed as lipstick base formulation.
\end{abstract}

Keywords: grape seed oil; lipstick base; low energy; water in oil nanoemulsions 


\section{Pendahuluan}

Lipstik telah digunakan oleh peradaban manusia sejak 500 tahun yang lalu. Pada awal penemuannya di jaman Mesopotamia Kuno, lipstik berupa pecahan batu yang digunakan untuk mewarnai bibir [1]. Di Perancis (1869), lipstik diperkenalkan sebagai sediaan kosmetik yang berbahan lemak hewani dan lilin dari lebah [2]. Bentuk sediaan lipstik dengan basis lilin dan lemak inilah yang kemudian berkembang hingga saat ini. Pada perkembangannya, lipstik menjadi kosmetik dekoratif yang berbahan dasar kombinasi antara lilin dan minyak (anhidrat). Namun belakangan ini fungsi lipstik tidak hanya sebagai pewarna bibir namun juga sebagai bahan pelembab bahkan lipstik digunakan sebagai pengantar obat melalui kulit bibir $[3,4]$.

Terkait dengan fungsi lipstik sebagai pelembab, air merupakan bahan dasar untuk melembabkan bibir. Selain itu, lipstik untuk keperluan medikasi terkadang juga perlu ditambahkan bahan-bahan yang bersifat hidrofilik, baik obatobatan yang bersifat hidrofilik mapun air itu sendiri. Namun penambahan air ataupun bahanbahan hidrofilik pada lipstik menjadi terkendala karena komponen dasar lipstik bersifat hidrofobik. Sistem emulsi air dalam minyak menjadi solusi untuk mengatasi permasalahan ini. Telah dilakukan beberapa percobaan pembuatan lipstik dengan menambahkan air dalam bentuk emulsi $[5,6]$, namun demikian ternyata penambahan air yang diemulsikan pada sediaan lipstik masih meninggalkan beberapa permasalahan misalnya diskolorasi, kurang homogennya pencampuran komponen-komponen lipstik, keluarnya air dari droplet pada saat pencetakan, dan berubahnya sifat fisik lipstik yang tidak diinginkan seperti mudah patah dan terlalu keras [7]. Untuk itu diperlukan sistem yang lebih baik untuk mengatasi hal ini karena dengan sistem emulsi air dalam minyak, lipstik hanya bisa menampung air atau bahan-bahan hidrofilik sebanyak $2 \%$. Sistem nanoemulsi air dalam minyak merupakan alternatif untuk mengatasi permasalahan ini karena sistem ini ternyata dapat meningkatkan jumlah air yang ditambahkan hingga 10\% [8].

Penggunaan energi tinggi (high pressure homogenizer) dalam pembuatan nanoemulsi seperti yang dilakukan oleh Promduoang (2010) menghasilkan karakter nanoemulsi yang kurang seragam serta investasi biaya tinggi untuk peralatan yang digunakan [8]. Oleh karena itu, masih perlu dilakukan investigasi pengembangan nanoemulsi air dalam minyak yang digunakan sebagai komponen sediaan lipstik dengan menggunakan energi rendah yang diharapkan bisa menjadi solusi untuk mengatasi permasalahan lipstik yang mengandung air. Pada penelitian sebelumnya, pembuatan basis lipstik yang menggunakan minyak zaitun telah menunjukkan peningkatan jumlah air yang dapat ditambahkan yakni mencapai $12 \%$ [9], sehingga perlu dilakukan penelitian lebih lanjut untuk lebih mengoptimalkan jumlah air dalam lipstik dengan menggunakan bahanbahan komponen yang beragam.

Pada penelitian ini dilakukan studi pengaruh air yang terformulasi pada nanoemulsi air dalam minyak biji anggur (Vitis vinifera L.) sebagai model fase minyak dengan menggunakan energi rendah yang dibuat dengan metode pembalikan fase terhadap karakteristik sediaan lipstik. Karakteristik fisik sediaan yang diamati meliputi kekerasan, titik lebur, dan daya sebar lipstik.

\section{Metode}

\subsection{Bahan}

Bahan-bahan yang digunakan dalam penelitian ini adalah minyak biji anggur (Brataco), tween 20 (kualitas farmasetis Brataco, Indonesia), span 80 (kualitas farmasetis Brataco, Indonesia), dan aquades yang berfungsi dalam pembentukan nanoemulsi. Cera alba, vaselin alba, setil alcohol, paraffin wax, dan metil paraben tersedia dari Laboratorium Teknologi Farmasi Universitas Islam Indonesia.

\subsection{Pembuatan diagram fase terner}

Nanoemulsi a/m minyak biji anggur dibuat dengan teknik PIC pada pemanasan suhu tinggi 
$\left(80^{\circ} \mathrm{C}\right)$. Diagram fase terner yang terdiri dari air, kombinasi surfaktan, dan minyak biji anggur dalam rasio volume $(\mu \mathrm{l})$ yang berbeda $(1: 1,1: 2$, $1: 3,2: 3$ ) digunakan untuk mengetahui pengaruh dari konsentrasi kombinasi surfaktan, air, dan minyak dicampur dengan bantuan vortex dalam rasio $(1: 1,1: 2,1: 3,1: 4,1: 5,1: 6,1: 7,1: 8$, 1:9). Penambahan minyak yang bervariasi dilakukan untuk menghasilkan konsentrasi minyak berkisar 3-78\% dari volume total dengan interval penambahan minyak sebanyak $\pm 5 \%$ hingga 100\% [10]. Pada setiap penambahan minyak dihomogenkan dengan bantuan magnetic stirrer yang suhunya dipertahankan pada $80^{\circ} \mathrm{C}$. Pada setiap penambahan fase minyak, dilihat secara visual keadaan fisik dari campuran (jernih atau keruh), keberadaan zona nanoemulsi dapat diilustrasikan dengan membangun diagram fase terner menggunakan software triplot 4.1.2. Dari diagram terner yang terbentuk, kemudian dipilih diagram dengan area terbesar yang bisa membentuk nanoemulsi.

\subsection{Pembuatan nanoemulsi air dalam minyak} biji anggur

Diagram yang memiliki luas area nanoemulsi yang terbesar, ditentukan 3 formula dengan seri kadar air yang optimal. Ketiga formula akan dilakukan evaluasi dan selanjutnya digunakan sebagai komponen dasar lipstik.

\subsection{Pembuatan emulsi air dalam minyak biji anggur}

Preparasi emulsi konvensional dibuat dengan komposisi kadar air dan minyak biji anggur sesuai dengan protokol 2.2., namun dengan jumlah surfaktan setara dengan jumlah air. Pengadukan dilakukan menggunakan ultra turrax homogenizer. Selanjutnya emulsi konvensional ini digunakan sebagai komponen dasar lipstik, lalu akan dibandingkan karakteristiknya dengan lipstik konvensional dan lipstik nanoemulsi.

\subsection{Evaluasi sediaan nanoemulsi}

Evaluasi ini untuk melihat pengaruh perbedaan kadar air pada ukuran partikel dan index polidispersitas ( $\mathrm{PDI}=$ polydispersity index). Uji ukuran globul dan PDI dilakukan dengan menggunakan Particle Size Analyzer (PSA) (Horiba SZ 100). Kondisi PSA disesuaikan dengan sampel nanoemulsi air dalam minyak biji anggur, yakni harga refraktif indeksnya. Sebagai medium pendispersi adalah minyak biji anggur dengan refraktif indeks 1,367 dan material terdispersi adalah air dengan refraktif indeks 1,313.

\subsection{Pembuatan lipstik}

Formula modifikasi lipstik nanoemulsi air dalam minyak biji anggur dapat dilihat pada Tabel 1 [11]. Proses pembuatan lipstik diawali dengan penimbangan bahan nanoemulsi air dalam minyak biji anggur dengan jumlah air yang berbeda secara terpisah dimasukkan ke dalam basis lipstik. Komposisi formula modifikasi pembuatan lipstik seperti Tabel 1. Nanoemulsi dimasukkan dalam cawan (campuran 1). Basis lipstik dileleh-

Tabel 1. Formulasi modifikasi basis lipstik nanoemulsi air dalam minyak biji anggur

\begin{tabular}{ll}
\hline Bahan & $\mathbf{\%}(\mathbf{b} / \mathbf{b})$ \\
\hline Nanoemulsi air dalam minyak biji anggur & 70 \\
Cera alba & 7,5 \\
Parafin wax & 2,5 \\
Lanolin & 2,5 \\
Setil alkohol & 4,92 \\
\hline Vaselin alba & 5,0 \\
\hline
\end{tabular}

Keterangan: Modifikasi formula pada kadar air dari nanoemulsi air dalam minyak biji anggur 
kan di atas penangas air pada suhu $80^{\circ} \mathrm{C}$. Pelelehan basis lipstik berdasarkan urutan titik lebur masing-masing bahan, yaitu dari titik lebur yang paling tinggi ke titik lebur yang paling rendah, dimana urutan pelelehan dasar lipstik dimulai dari cera alba, vaselin alba, lanolin, parafin wax, dan setil alkohol. Semua dasar lipstik yang meleleh dengan sempurna kemudian ditambahkan sedikit demi sedikit campuran 1 sambil terus diaduk untuk menghindari pengerasan [11]. Setelah dasar lipstik homogen, dimasukkan ke dalam cetakan dan didinginkan dalam lemari pendingin $\left(-2^{\circ} \mathrm{C}\right)$ selama 10 menit [8].

\subsection{Evaluasi sediaan lipstik}

\subsubsection{Uji kekuatan lipstik}

Dilakukan pengamatan terhadap kekuatan lipstik dengan cara lipstik diletakkan horizontal dengan jarak $1 \frac{1}{2}$ inci dari tepi lipstik dan digantungkan beban yang berfungsi sebagai penekan, kemudian ditambah beban penekan sebanyak 10 gram setiap 30 detik. Penambahan berat beban dilakukan terus-menerus sampai lipstik patah dan pada saat lipstik patah itu merupakan nilai kekuatan lipstiknya [8].

\subsubsection{Uji daya sebar}

Dilakukan pengamatan terhadap daya sebar lipstik dengan mengoleskan ujung lipstik pada kaca transparan. Diamati permukaan lipstik yang terlihat pada kaca transparan. Daya sebar yang baik terlihat dari permukaan lipstik yang halus saat dioleskan pada kaca transparan [12].

\subsubsection{Uji titik lebur}

Pengamatan dilakukan terhadap titik lebur lipstik dengan cara meleburkan lipstik. Sediaan lipstik yang baik adalah sediaan lipstik dengan titik lebur di atas $50^{\circ} \mathrm{C}$. Lipstik dimasukkan ke dalam pipa kapiler kaca dengan tinggi 2,5-3,5 $\mathrm{mm}$. Tangas dipanaskan hingga suhu $\pm 10^{\circ} \mathrm{C}$ di bawah suhu lebur lipstik dan dinaikkan suhunya dengan kecepatan $1^{\circ} \mathrm{C} \pm 0,5^{\circ} \mathrm{C}$ per menit. Kapiler dimasukkan, bila suhu mencapai $5^{\circ} \mathrm{C}$ di bawah suhu terendah yang diperkirakan dilanjutkan pe- manasan hingga melebur sempurna dan dicatat jarak leburnya [12].

\subsection{Analisis data}

Data yang diperoleh baik dari evaluasi nanoemulsi maupun evaluasi lipstik ditampilkan dalam bentuk rerata \pm SD. Normalitas data diuji dengan Shapiro-Wilk atau Kolmogorov Smirnov. Jika data terdistribusi normal $(\mathrm{P}>0,05)$ maka dilanjutkan dengan uji parametrik analysis of variance (ANOVA) dengan taraf kepercayaan 95\%. Jika pada uji parametrik ANOVA menunjukkan perbedaan yang signifikan $(\mathrm{P}<0,05)$ maka dilanjutkan Pos Hoc Test, namun jika tidak berbeda signifikan (P > 0,05) maka Pos Hoc Test tidak dilakukan. Apabila data tidak memenuhi syarat untuk dilakukan uji parametrik ANOVA maka dilanjutkan menggunakan uji non parametrik menggunakan Kruskal Wallis.

\section{Hasil dan pembahasan}

\subsection{Diagram fase terner nanoemulsi air dalam minyak}

Pembuatan nanoemulsi minyak biji anggur dengan energi rendah ini menggunakan surfaktan non ionik tanpa penambahan kosurfaktan. Penelitan sebelumnya mengungkapkan bahwa emulsi m/a tanpa kosurfaktan stabil, yang dapat dilihat dari diagram fase terner (minyak-air-surfaktan) untuk beberapa surfaktan (tween 20, 40, 60,80 , serta span 20 dan 80) [9]. Hal ini menunjukkan bahwa kemampuan pengemulsi surfaktan tersebut telah efisien. Konsep surfaktan merupakan senyawa aktif permukaan sehingga mampu menurunkan tegangan antar muka antara minyak dan air $[9,13]$. Menurut penelitian yang mempelajari sebuah emulsifier lipofilik, seperti span 60 (HLB 4,7), span 80 (HLB 4,3) dan emulsifier hidrofilik misalnya tween 20 (HLB 16,7), sistem emulsifier tersebut digunakan untuk menstabilkan emulsi pada lipstik. Hal ini disebabkan tween 20 dan span 80 merupakan surfaktan non ionik. Tween 20 bersifat hidrofilik dan span 80 
bersifat lipofilik. Senyawa yang bersifat hidrofilik dan lipofilik yang terbentuk pada lapisan keduanya, dapat membentuk titik keseimbangan (hydrophilic-lipophilic balance, HLB), oleh sebab itu pada saat fase minyak bergabung ke fase minyak, sedangkan yang fase air bergabung ke fase air dan pada saat kondisi penurunan tegangan permukaan terjadi [14].

Setelah melakukan studi pada beberapa surfaktan, penelitian ini menggunakan kombinasi surfaktan antara tween 20 dan span 80, dengan penambahan rasio dalam sistem yang ditentukan. Dalam beberapa tahun terakhir nanoemulsi $\mathrm{a} / \mathrm{m}$ telah dipelajari, tetapi penelitian tentang nanoemulsi $\mathrm{a} / \mathrm{m}$ jarang dilakukan. Beberapa peneliti telah mempelajari nanoemulsi a/m atau miniemulsi a/m dan melaporkan pembentukan nanoemulsi dengan campuran non ionik surfaktan sesuai dengan ukuran dan stabilitas nanoemulsi [15]. Komposisi bahan untuk pembuatan diagram fase terdiri dari fase air, fase minyak biji anggur, dan fase kombinasi surfaktan (tween 20 dan span 80).

Perbandingan kombinasi surfaktan menunjukkan bahwa jumlah span 80 yang lebih besar atau sama dibandingkan dengan tween 20 akan membentuk area nanoemulsi, hal ini dikarenakan span 80 bersifat lipofil. Akan tetapi, jumlah span 80 dan tween 20 dengan perbandingan sama hanya terjadi pada perbandingan 1:9, 1:8, 1:7, 1:6, dan 1:5 (Tabel 2). Pada Gambar 1, daerah yang menunjukkan terbentuknya area nanoemul-

Tabel 2. Perancangan pembuatan diagram fase terner

\begin{tabular}{|c|c|c|c|c|c|c|c|c|c|}
\hline \multirow{2}{*}{$\begin{array}{l}\text { Perbandingan } \\
\text { surfaktan } \\
\text { (tween } 20: \text { span 80) }\end{array}$} & \multicolumn{9}{|c|}{$\begin{array}{l}\text { Perbandingan } \\
\text { (air: kombinasi surfaktan) }\end{array}$} \\
\hline & 1:9 & $1: 8$ & 1:7 & $1: 6$ & 1:5 & 1:4 & $1: 3$ & $1: 2$ & 1:1 \\
\hline $1: 1$ & $\mathrm{NE}$ & $\mathrm{NE}$ & $\mathrm{NE}$ & $\mathrm{NE}$ & $\mathrm{NE}$ & E & $\mathrm{E}$ & $E$ & $\mathrm{E}$ \\
\hline $1: 2$ & $\mathrm{NE}$ & $\mathrm{NE}$ & $\mathrm{NE}$ & $\mathrm{NE}$ & $\mathrm{E}$ & E & $\mathrm{E}$ & $\mathrm{E}$ & E \\
\hline $1: 3$ & $\mathrm{NE}$ & $\mathrm{NE}$ & $\mathrm{NE}$ & E & $\mathrm{E}$ & E & $\mathrm{E}$ & E & $\mathrm{E}$ \\
\hline $2: 3$ & $\mathrm{NE}$ & $\mathrm{NE}$ & $\mathrm{NE}$ & $\mathrm{NE}$ & $\mathrm{NE}$ & E & E & E & $\mathrm{E}$ \\
\hline
\end{tabular}

Keterangan: $\mathrm{E}=$ Emulsi, $\mathrm{NE}=$ Nano Emulsi

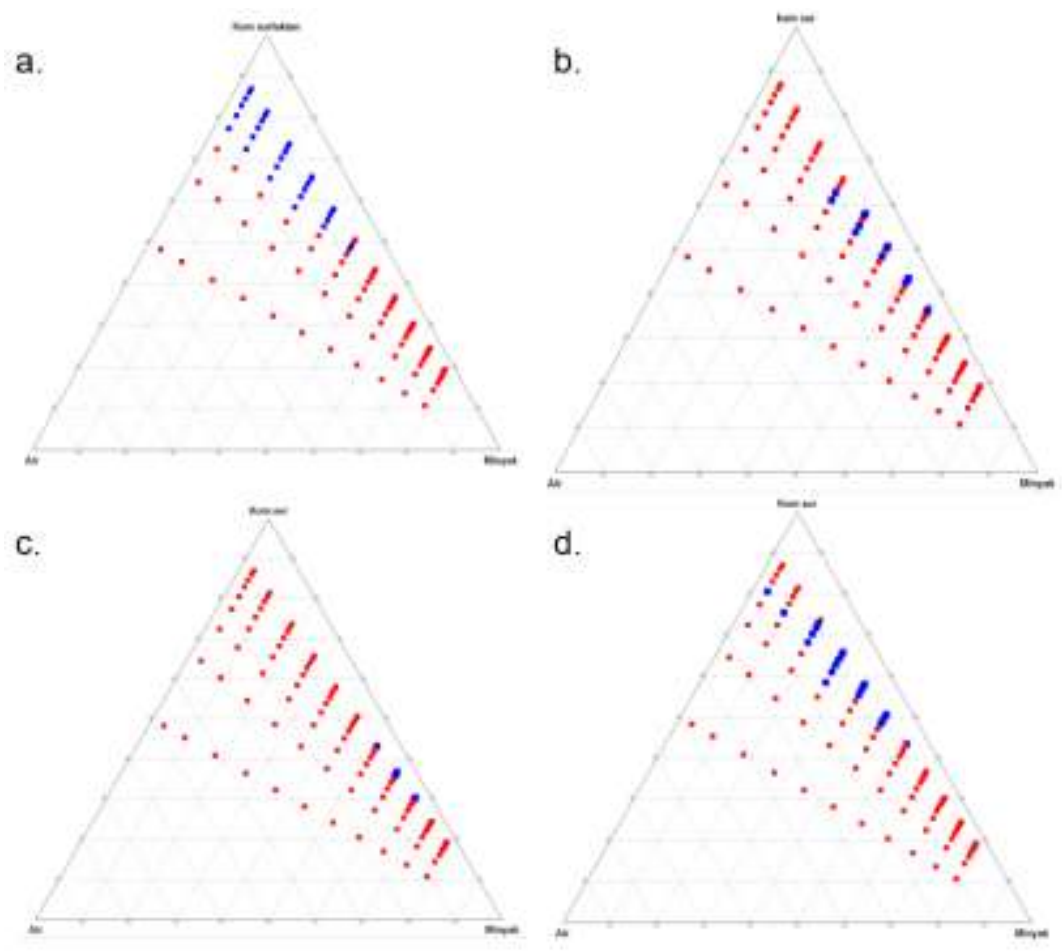

Gambar 1. Diagram fase terner. Kombinasi surfaktan tween 20-span 80 adalah 1:1 (a); 1:2 (b), 1:3 (c), dan $2: 3(d)$ 
si dengan titik berwarna biru dan area bikontinyu dengan warna merah, dari Gambar 1a didapatkan bahwa perbandingan 1:1 menunjukkan bahwa nanoemulsi yang paling luas dan hasil yang didapatkan jernih secara visual dari awal sampai akhir titrasi.

Dari hasil pembuatan diagram fase terner dapat dihasilkan nanoemulsi air dalam minyak biji anggur dengan kadar air hingga 20\%. Surfaktan ditetapkan $60 \%$ karena pada penelitian ini hanya melihat pengaruh air bukan surfaktan. Oleh karena itu, rasio air divariasikan 6, 10, dan 14\%. Kemampuan kombinasi surfaktan dalam melarutkan fase minyak menentukan luas wilayah nanoemulsi. Komposisi span 80 yang lebih banyak mengakibatkan tegangan antarmuka dua cairan yang tidak dapat saling bercampur semakin menurun. Penambahan tween 20 juga lebih membantu dalam menurunkan tegangan antarmuka melalui peningkatan fluiditas antarmuka yang terbentuk dalam proses pembentukan nanoemulsi yang stabil secara termodinamika [16].

\subsection{Pengaruh rasio air pada ukuran globul dan PDI nanoemulsi air dalam minyak biji anggur}

Berdasarkan data yang telah dihasilkan, pembuatan diagram fase terner didapatkan area terluas yaitu 1:1 serta batas atas dan batas bawah dari konsentrasi minyak, surfaktan, dan air divariasikan menjadi 3 kadar yang berbeda yaitu 6 , 10, dan 14\%. Nanoemulsi yang terbentuk dilakukan karakterisasi meliputi ukuran globul dan indeks polidispersitas dan hasilnya ditunjukkan pada Tabel 3.

Ukuran globul pada ketiga formula nanoemulsi antara 74,4-96,8 nm, nilai indeks polidispersitas (PDI) antara 0,406-0,584 dengan komposisi air 6-14\%, minyak 26-34\%, dan kombinasi sur- faktan $60 \%$ (Tabel 3). Namun ternyata analisis statistik menunjukkan tidak ada perbedaan yang signifikan $(P>0,05)$ baik pada ukuran globul maupun PDI, sehingga dapat diambil kesimpulan bahwa dari berbagai variasi kadar air pada nanoemulsi air dalam minyak biji anggur tidak memberikan pengaruh yang signifikan pada ukuran globul dan PDI.

Berdasarkan hasil formula sediaan nanoemulsi air dalam minyak biji anggur formula 1, 2, dan 3 memperlihatkan hasil bahwa sediaan nanoemulsi berupa sediaan yang transparan atau jernih serta stabil karena pada sediaan yang dibuat tidak terjadi pemisahan fase (Gambar 2). Nanoemulsi dengan ukuran globul yang kecil akan menghasilkan sediaan yang transparan atau jernih dan atau sedikit bergelembung, sehingga sangat cocok digunakan dalam industri kosmetik, makanan, atau obat [17].

Adapun grafik distribusi ukuran partikel yang ditunjukkan pada Gambar 3 yang memiliki pola 1 puncak (unimodal) [19] dengan konsentrasi surfaktan yang sama, maka konsentrasi air dan minyak dapat menurunkan stabilitas nanoemulsi [20]. Data distribusi ukuran juga didukung dari nilai indeks polidespersitas. Semakin rendah nilai indeks polidispersitasnya maka semakin tinggi keseragaman ukuran globul dalam formula. Tabel 3 menunjukkan adanya kecenderungan ukuran globul tertinggi pada kadar air 10\% namun perbedaan tersebut tidak signifikan $(P>0,05)$ sehingga dapat disimpulkan bahwa peningkatan kadar air pada nanoemulsi air dalam minyak biji anggur tidak berpengaruh pada indeks polidispersitas.

\subsection{Pengaruh kandungan air nanoemulsi air dalam minyak biji anggur pada karakteristik fisik lipstik}

Tabel 3. Formula nanoemulsi dan respon ukuran partikel serta PDI

\begin{tabular}{llllll}
\hline Formula & Air (\%) & Minyak (\%) & $\begin{array}{l}\text { Kombinasi surfaktan } \\
\text { (tween 20:span 80; \%) }\end{array}$ & $\begin{array}{l}\text { Ukuran partikel } \\
\text { (rerata } \pm \text { SD; nm) }\end{array}$ & PDI (rerata \pm SD) \\
\hline 1 & 6 & 34 & 60 & $80,33 \pm 5,20$ & $0,476 \pm 0,043$ \\
2 & 10 & 30 & 60 & $90,33 \pm 7,49$ & $0,490 \pm 0,071$ \\
3 & 14 & 26 & 60 & $87,2 \pm 4,42$ & $0,475 \pm 0,095$ \\
\hline
\end{tabular}




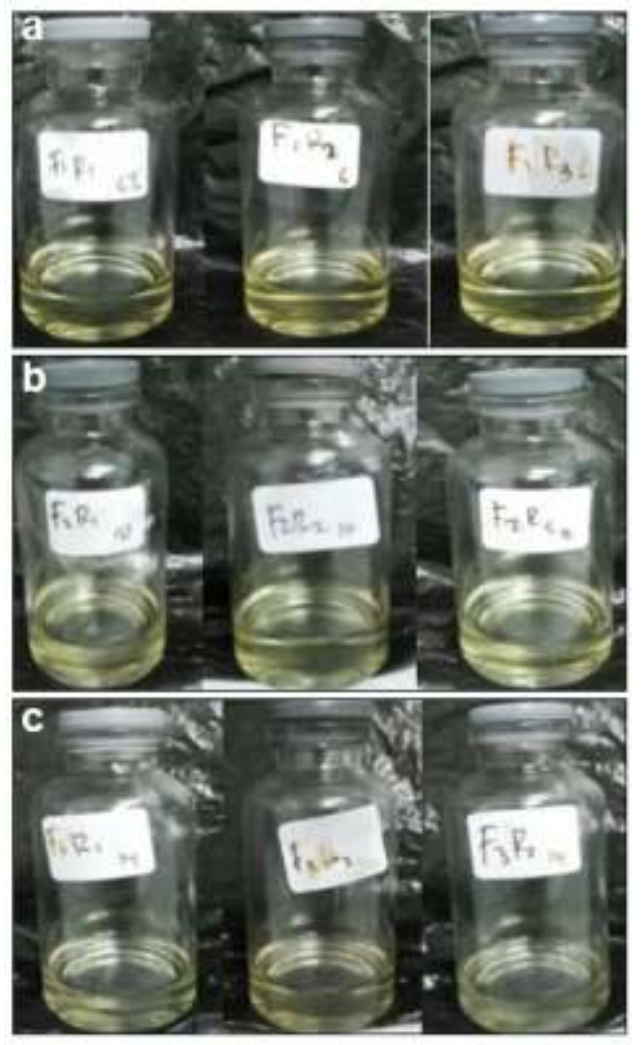

Gambar 2. Sediaan nanoemulsi dengan 3 variasi kadar air: 6\% (a), 10\% (b), dan 14\% (c)

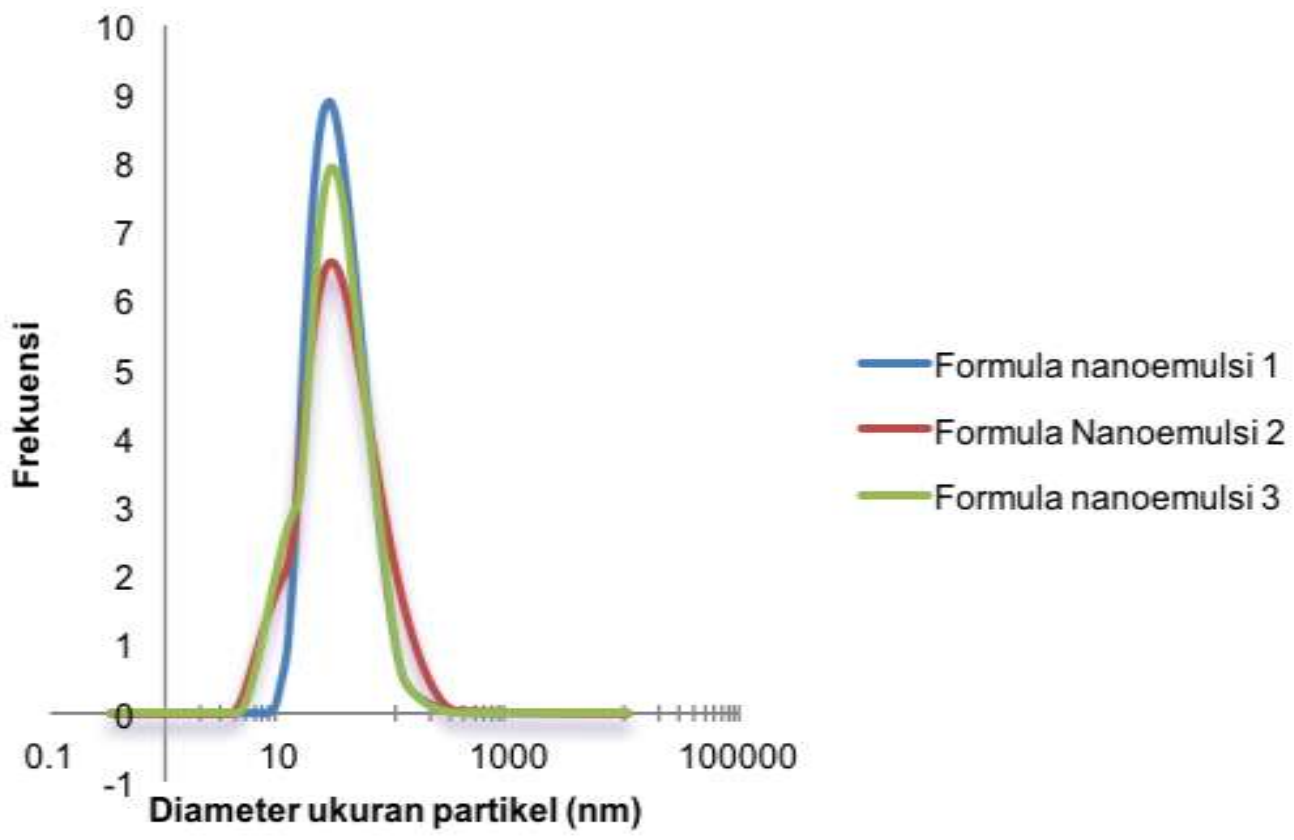

Gambar 3. Grafik distribusi ukuran partikel

\subsubsection{Kekerasan lipstik}

Hasil uji kekerasan lipstik nanoemulsi air dalam minyak biji anggur menunjukkan bahwa sediaan lipstik yang memiliki nilai breaking point paling tinggi terdapat pada formula nanoemulsi $\mathrm{a} / \mathrm{m}$ dengan kadar air 14\% (Tabel 4). Namun demikian, secara statistik tidak ada perbedaan kekerasan pada nanoemulsi air dalam minyak biji anggur yang signifikan $(P>0,05)$ sehingga disimpulkan bahwa perbedaan kandungan air pada 
Tabel 4. Hasil uji kekerasan lipstik

\begin{tabular}{lll}
\hline No & Formula lipstik & Nilai kekerasan Lipstik (g) \\
\hline 1 & Lipstik Nanoemulsi 6\% & $143,33 \pm 5,773$ \\
2 & Lipstik Nanoemulsi 10\% & $146,66 \pm 4,082$ \\
3 & Lipstik Nanoemulsi 14\% & $146,66 \pm 4,082$ \\
4 & Lipstik Emulsi 6\% & $126,66 \pm 5,733$ \\
5 & Lipstik Emulsi 10\% & $126,66 \pm 5,733$ \\
\hline 6 & Lipstik Emulsi 14\% & $123,33 \pm 4,082$ \\
\hline 7 & Lipstik konvensional & $96,66 \pm 8,164$ \\
\hline
\end{tabular}

Tabel 5. Hasil uji titik lebur lipstik

\begin{tabular}{lll}
\hline No & Formula lipstik & Nilai titik lebur $\left({ }^{\circ} \mathbf{C}\right)$ \\
\hline 1 & Lipstik Nanoemulsi 6\% & $52,33 \pm 0,76$ \\
2 & Lipstik Nanoemulsi 10\% & $53,33 \pm 1,15$ \\
3 & Lipstik Nanoemulsi 14\% & $54,00 \pm 1,00$ \\
4 & Lipstik Emulsi 6\% & $47,33 \pm 0,40$ \\
5 & Lipstik Emulsi 10\% & $48,00 \pm 0,70$ \\
6 & Lipstik Emulsi 14\% & $48,33 \pm 0,81$ \\
\hline 7 & Lipstik konvensional & $46,66 \pm 0,81$ \\
\hline
\end{tabular}

nanoemulsi $\mathrm{a} / \mathrm{m}$ minyak biji anggur tidak berpengaruh pada kekerasan lipstik. Hal ini merupakan peluang mengembangkan lipstik berbasis nanoemulsi a/m dengan menambahkan jumlah air yang optimal. Hal ini tidak berlaku pada lipstik dengan basis emulsi $\mathrm{a} / \mathrm{m}$, karena berdasarkan analisis statistik perbedaan kandungan air pada emulsi a/m minyak biji anggur berpengaruh pada kekerasan lipstiknya $(\mathrm{P}<0,05)$. Jika dibandingkan dengan lipstik konvensional, terdapat perbedaan kekerasan yang signifikan baik terhadap lipstik nanoemulsi maupun lipstik emulsi. Hal ini disebabkan karena nanoemulsi memiliki ukuran droplet yang kecil sehingga peningkatan air ketika diformulasikan ke dalam lipstik nanoemulsi tidak mempengaruhi kekerasan lipstik sediaan nanoemulsi. Berbeda halnya dengan lipstik emulsi, penambahan air dengan jumlah tinggi akan mempercepat kristalisasi dari komponen bahan sediaan lipstik seperti lipid, lilin sehingga tekstur lipstik yang diperoleh lebih padat dan tidak mudah patah jika dibandingkan dengan formula lipstik konvensional yang mempunyai nilai breaking point yang rendah karena tekstur lipstik yang cenderung lembek. Selain itu ukuran kristal pada lilin tergantung juga pada jumlah air dalam formulasi, semakin tinggi kadar air maka akan semakin tinggi ukuran kristal diamati. Hal ini dapat disebabkan ketika air diformulasikan dalam jumlah tinggi ke emulsi, memberikan kekerasan yang berlebih kepada lipstik karena ada kemungkinan peningkatan fase air dapat meningkatkan secara proporsional dengan konsentrasi surfaktan yang terdapat pada sediaan lipstik nanoemulsi dan lipstik emulsi $[8,18]$.

\subsubsection{Titik lebur lipstik}

Tabel 5 menunjukkan bahwa lipstik nanoemulsi mempunyai titik lebur yang lebih tinggi dibandingkan lipstik emulsi maupun lipstik konvensional. Semakin tinggi kadar air pada sediaan nanoemulsi yang diformulasikan ke dalam dasar lipstik maka akan semakin tinggi titik leburnya. Hal ini terjadi akibat dasar lipstik yang mengandung lebih banyak air akan menaikkan titik lebur dari lipstik karena basis air sulit untuk melebur 

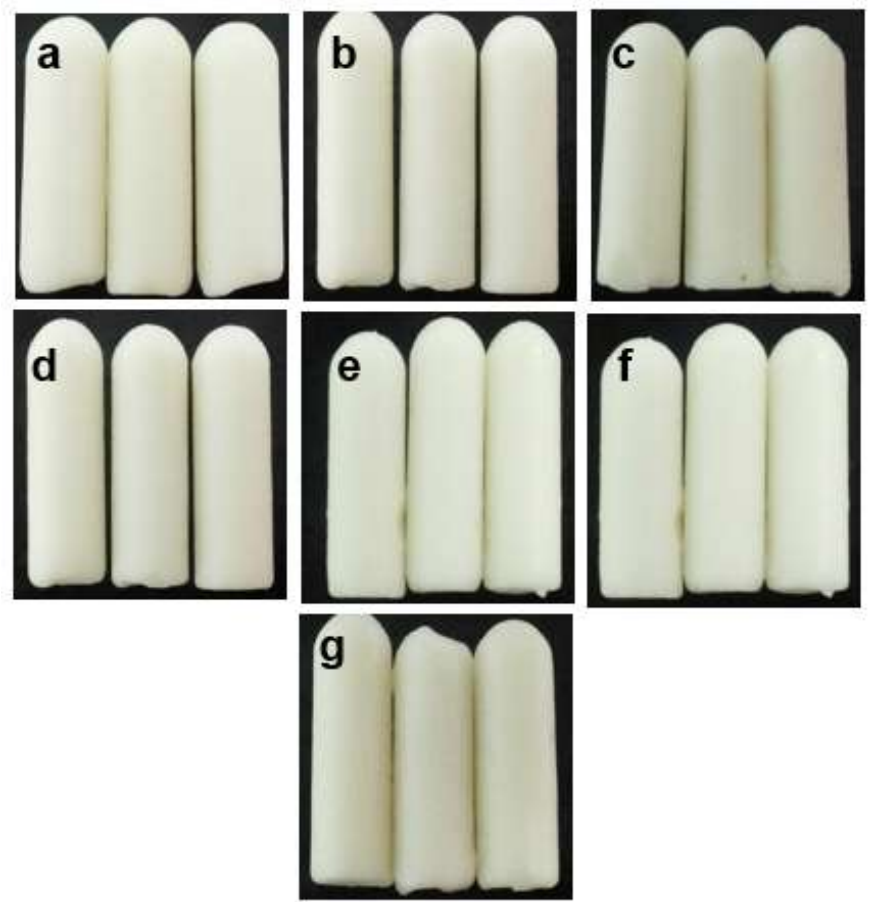

Gambar 4. Sediaan lipstik: lipstik nanoemulsi kadar air 6\% (a), 10\% (b), 14\% (c); lipstik emulsi kadar air $6 \%$ (d), 10\% (e), 14\% (f); lipstik konvensional (g)
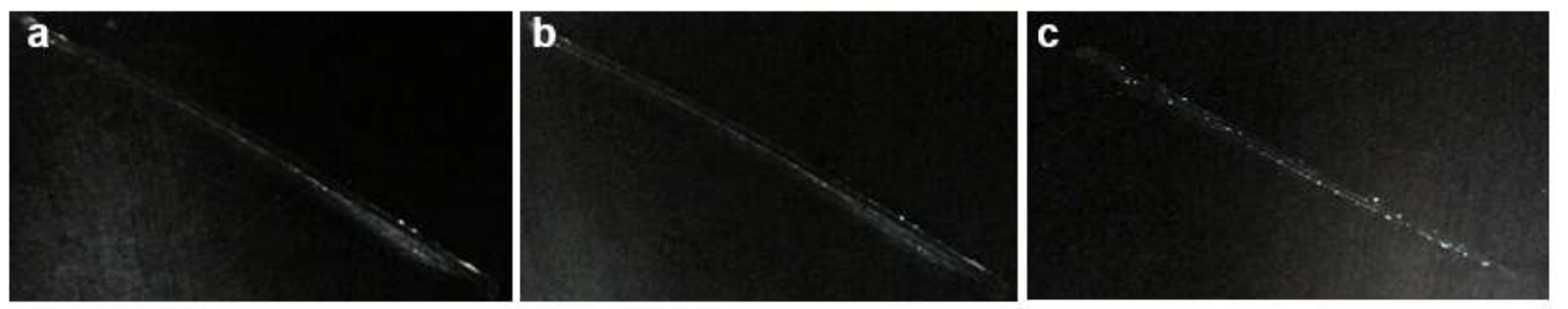

Gambar 5. Permukaan lipstik pada kaca dengan latar belakang hitam (gelap): lipstik nanoemulsi (a), lipstik emulsi (b), lipstik konvensional (c)

karena air memberikan struktur sediaan yang padat dan ketika air diformulasikan dalam jumlah tinggi ke emulsi dan nanoemulsi dapat meningkatkan secara proporsional konsentrasi surfaktan yang terdapat pada sediaan lipstik nanoemulsi dan emulsi $[18,21,22]$. Dari hasil uji Tukey, titik lebur dari 3 lipstik nanoemulsi dengan variasi kadar air 6, 10, dan 14\% dinyatakan tidak berbeda secara signifikan $(P>0,05)$, yang artinya kandungan air dalam nanoemulsi tidak berpengaruh secara signifikan terhadap sifat fisik lipstik. Namun demikian, pada lipstik dengan basis emulsi perbedaan kandungan air ternyata berpengaruh karena hasil analisis statistik menunjukkan perbedaan yang bermakna $(\mathrm{P}<0,05)$ pada titik lebur lipstik, demikian juga pada lipstik konvensional yang rendah titik leburnya.

\subsubsection{Daya sebar lipstik}

Sediaan lipstik yang dihasilkan mempunyai penampilan yang merata dan homogen pada semua formula (Gambar 4), namun untuk melihat homogenitasnya, maka dilakukan pengujian daya sebar. Sediaan lipstik dapat dikatakan mempunyai daya sebar yang baik jika sediaan memberikan olesan yang halus dan rata, tidak terdapat butir-butir kasar atau grity ketika dioleskan pada kaca objek. Adanya butir-butir kasar pada permukaan kaca transparan menandakan sediaan lipstik tidak homogen karena tidak terdispersinya antar komponen lipstik [23]. Pada penelitian ini uji daya sebar dilakukan dengan cara mengoleskan bagian ujung lipstik pada kaca transparan, lalu dilihat ada tidaknya grity. 
Berdasarkan hasil yang diperoleh dari uji daya sebar (Gambar 5), terlihat bahwa sediaan yang memiliki daya sebar yang baik adalah sediaan nanoemulsi dengan variasi kadar air 6, 10, dan 14\%. Hal ini ditandai dengan 3 kali pengolesan lipstik pada kaca transparan rata. Uji daya sebar pada lipstik emulsi (Gambar 5) juga menunjukkan hasil yang cukup baik pada masing-masing variasi air $(6,10$, dan 14\%). Namun demikian, masih terdapat sedikit permukaan kasar. Berbeda halnya dengan lipstik konvensional yang saat dioleskan secara merata di atas kaca objek memperlihatkan adanya permukaan yang kasar dan hal ini menandakan bahwa antar komponen pada lipstik konvensional tidak terdispersi dengan baik.

\section{Kesimpulan}

Dengan energi rendah, telah dapat dihasilkan nanoemulsi air dalam minyak biji anggur dengan kadar air hingga 20\%. Dari 3 formula nanoemulsi yang kadar airnya masing-masing divariasikan 6, 10, dan $14 \%$, penambahan air tidak berpengaruh secara signifikan $(\mathrm{P}>0,05)$ pada ukuran globul dan indeks polidispersitas nanoemulsi air dalam minyak biji anggur. Pada sifat fisik lipstik, penambahan air yang terformulasi dalam nanoemulsi air dalam minyak biji anggur tidak berpengaruh secara signifikan $(\mathrm{P}>0,05)$ terhadap kekerasan dan titik lebur lipstik. Lipstik dengan basis nanoemulsi air dalam minyak biji anggur memberikan sifat lipstik yang lebih baik daripada lipstik konvensional, dengan demikian nanoemulsi air dalam minyak biji anggur dapat dikembangkan sebagai komponen basis lipstik.

\section{Ucapan terima kasih}

Penelitian ini dibiayai oleh Hibah Akreditasi Institusi Perguruan Tinggi (AIPT) yang diselenggarakan oleh Badan Pengembangan Akademik (BPA) Universitas Islam Indonesia (UII), Yogyakarta, Indonesia.

\section{Daftar Pustaka}

1. Kozlowski K. Read my lips: A cultural history of lipstick. Chronicle Books; 1998.

2. Berg R. Beauty: the new basics. New York: Workman Publishing; 2001.

3. Shaikh S, Bhise K. Formulation and evaluation of medicated lipstick of allantoin. Asian Journal of Pharmaceutics. 2008;2(2):91-5.

4. Majumdar SH, Kakadiya BL. Desiging medicated lipstick for anti-fungal therapy. American Journal of Pharm Research. 2015;5(2).

5. Le Révérend BJ, Taylor MS, Norton IT. Design and application of water-in-oil emulsions for use in lipstick formulations. International Journal of Cosmetic Science. 2011;33(3):263-8.

6. Beri A, Norton JE, Norton IT. Effect of emulsifier type and concentration, aqueous phase volume and wax ratio on physical, material and mechanical properties of water in oil lipsticks. International Journal of Cosmetic Science. 2013;35(6):613-21.

7. Dunphy PJ, Meyers AJ, Rigg RT, inventors; Elizabeth Arden Inc, assignee. Cosmetic water-in-oil emulsion lipstick comprising a phospholipid and glycerol fatty acid esters emulsifying system. United States patent US 5,085,856. 1992 Feb 4.

8. Promdouang P. Development of water in oil nanoemulsion lipsticks. Doctoral dissertation, Chulalongkorn University; 2010.

9. Munawiroh SZ, Nabila AN, Chabib L. Development of Water in Olive Oil (W/O) Nanoemulsions as Lipstick Base Formulation. Int J Pharma Med Biol Sci. 2017;6(2):37-42

10. Shafiq-un-Nabi S, Shakeel F, Talegaonkar S, Ali J, Baboota S, Ahuja A, Khar RK, Ali M. Formulation development and optimization using nanoemulsion technique: a technical note. AAPS Pharmscitech. 2007;8(2):E12-7.

11. Chabib L, Rizki MI, Hayati F. Formulasi Nanopartikel Karotenoid ekstrak Wortel (Daucus carrota L.) sebagai Pewarna Lipstik. DPPM UII. 2011:809-22.

12. Ditjen POM. Formularium Kosmetika Indonesia. Jakarta: Departemen Kesehatan RI. 1985;29(103):356-7.

13. Polychniatou V, Tzia C. Study of Formulation and 
Stability of Co-surfactant Free Water-in-Olive Oil Nano- and Submicron Emulsions with Food Grade Non-ionic Surfactants. Journal of the American Oil Chemists' Society. 2014;91(1):79-88.

14. Wang T-S, Lee G. The effect of formulation on the hardness and crystallization of emulsion lipsticks. Journal of the Society of Cosmetic Chemists. 1997;48(1):41-50.

15. Porras M, Solans C, González C, Gutiérrez JM. Properties of water-in-oil (W/O) nano-emulsions prepared by a low-energy emulsification method. Colloids and Surfaces A: Physicochemical and Engineering Aspects. 2008;324(1-3):181-8.

16. Elnaggar YS, El-Massik MA, Abdallah OY. Self-nanoemulsifying drug delivery systems of tamoxifen citrate: design and optimization. International Journal of Pharmaceutics. 2009;380(1):133-41.

17. McClements DJ. Edible nanoemulsions: fabrication, properties, and functional performance. Soft Matter. 2011;7(6):2297-316.

18. Pan H, Yu L, Xu J, Sun D. Preparation of highly stable concentrated W/O nanoemulsions by PIC method at elevated temperature. Colloids and Sur- faces A: Physicochemical and Engineering Aspects. 2014;447:97-102.

19. Han Z, Weng W, Huang Q. Characterizations of particle size distribution of the droplets exhaled by sneeze. Journal of The Royal Society Interface. 2013;10(88):20130560.

20. El-Din MN, El-Hamouly SH, Mohamed H, Mishrif MR, Ragab AM. Water-in-diesel fuel nanoemulsions: Preparation, stability and physical properties. Egyptian Journal of Petroleum. 2013;22(4):517-30.

21. Barel AO, Paye M, Maibach HI. Handbook of cosmetic science and technology. Boca Raton, Florida: CRC Press; 2014.

22. Kamairudin N, Gani SSA, Masoumi HRF, Hashim P. Optimization of natural lipstick formulation based on pitaya (Hylocereus polyrhizus) seed oil using Doptimal mixture experimental design. Molecules. 2014;19(10):16672-83.

23. Siregar YDI, Utami P. Pemanfaatan Ekstrak Kulit Melinjo Merah (Gnetum Gnemon) sebagai Pewarna Alami pada Pembuatan Lipstik. Jurnal Kimia Valensi. 2014;4(2):98-108. 